\title{
Physiological condition and barnacle larval behavior: a preliminary look at the relationship between TAG/DNA ratio and larval substratum exploration in Balanus amphitrite
}

\author{
Gilles Miron*, Linda J. Walters ${ }^{* *}$, Réjean Tremblay ${ }^{* *}$, Edwin Bourget \\ GIROQ, Département de biologie, Université Laval, Québec, Québec G1K 7P4, Canada
}

\begin{abstract}
Behavior of laboratory-reared larvae of the barnacle Balanus amphitrite was examined in Beaufort, North Carolina (USA), in relation to their physiological condition. Cyprid substratum exploration was monitored by means of video endoscopy using various experimental surface types (clean, biofilm, 1 and 2 wk fouled) and 2 water flow regimes (still water and ca $5 \mathrm{~cm} \mathrm{~s}^{-1}$ ) at room temperature $\left(21^{\circ} \mathrm{C}\right.$ ). We used the triacylglycerol/DNA (TAG/DNA) ratio of small batches of larvae as a measure of physiological condition in 0 to $12 \mathrm{~d}$ old cyprids. The physiological condition of cyprids decreased significantly with age $(p<0.001)$, ratios severely dropping between 5 and $8 \mathrm{~d}$. Although exploration behavior did not show much variation with age, the overall number of active exploring cyprids appeared to be age dependent. Additionally, the relationship between surface exploration behavior and age also appeared to vary with substratum type as well as flow rate. For example, fewer young cyprids $(0$ to $5 \mathrm{~d}$ old) explored unfavorable substrata (clean and biofilm treatments) than older ones in still water. Exploration responses, however, appeared to differ in relation to flow regimes (still vs moving water trials). Time spent by cyprids on surfaces before returning to the water column (nonexploratory behavior) appeared to vary in relation to age and substratum type in still water trials. Duration of exploration and distance explored by cyprids in flow generally peaked with cyprids from the $3 \mathrm{~d}$ cohort. Overall, our results showed that habitat selection in barnacle cyprids results from a complex relationship involving substratum type, hydrodynamics and larval age (i.e. physiological condition and competency).
\end{abstract}

KEY WORDS: Balanus amphitrite $\cdot$ Barnacle $\cdot$ Cyprid · Larval behavior $\cdot$ Larval ecology $\cdot$ Lipid condition - TAG/DNA ratio

Present addresses:

-Département de biologie, Université de Moncton, Moncton, Nouveau-Brunswick E1A 3E9, Canada.

E-mail: mirong@umoncton.ca

**Department of Biology, University of Central Florida, Orlando, Florida 32816, USA

***Centre aquicole marin, Ministère de l'Agriculture, des Pêcheries et de l'Alimentation, Direction générale des Pêches et de l'Aquiculture commerciales, Grande-Rivière, Québec G0C 1V0, Canada
Settlement and recruitment processes have been extensively studied in marine benthic invertebrates (e.g. Crisp 1976, 1984, Hadfield 1998). The effects of a wide variety of biotic (e.g. competition, predation) and abiotic (e.g. environmental conditions, substratum types, water flow) factors have been documented in many experimental field studies, and later used in conceptual models, to explain the variability in the population dynamics of marine organisms (e.g. Connell 1975, Paine 1977, Menge \& Sutherland 1976, Underwood \& Denley 1984). More recently, this variability has been related to a large set of factors that may enhance or impede the ability of individuals to perform (e.g. settlement, selection of habitat, attachment) during their larval phase (reviews: Pawlik 1992, Eckman 1996). For instance, studies have shown that population size and distribution patterns of several sessile invertebrate species are determined by passive dispersal processes (e.g. Grosberg 1982, Caffey 1985, Gaines \& Roughgarden 1985, Gaines et al. 1985, Minchinton \& Scheibling 1991, Miron et al. 1995) and by active exploration of the substrata which may lead to permanent attachment (e.g. Keough \& Downes 1982, Yule \& Walker 1987, Mullineaux \& Butman 1991, Walters 1992, Miron et al. 1996, Walters et al. 1999).

Although conceptual models in population dynamics of marine benthic species are becoming more realistic (Menge \& Sutherland 1987, Miron et al. 1999), the picture is yet to be completed. For instance, endogenous factors such as the physiological condition of a larva may also play a major role in habitat selection (Miron et al. 1999) and ultimately in population dynamics (Holland \& Walker 1975, Waldock \& Holland 1978, Lucas et al. 1979, Gallager et al. 1986, West \& Costlow 1987, Woollacott et al. 1989, Ouellet et al. 1992, Pechenik et al. 1993, 1996, Jaeckle 1994). Recently, 
Jarrett \& Pechenik (1997) showed that the organic content in cypris larvae of the barnacle Semibalanus balanoides explains temporal variations in metamorphic success and early juvenile mortality and growth. Poor physiological quality resulted in poor juvenile growth (Jarrett \& Pechenik 1997); this may in turn lead to poor competition capabilities (Connell 1961, Bertness 1989). Miron et al: (1999) also suggested that larval substratum exploration and decision processes regarding final attachment location in barnacles might depend on the physiological quality of cyprids. In their study, the physiological quality of newly settled $S$. balanoides (triacylglycerol[TAG]/cholesterol ratio) was greatest at low intertidal level, the preferred attachment location. However, the quality of planktonic cyprids was not correlated to their position in the water column (Miron et al. 1995, 1999). Planktonic cyprids dispiaying better physiological condition attach more readily to optimal spots compared to those in poorer condition. Cyprids' attachment specificity and ability are known to diminish over time (Rittschof et al. 1984, Satuito et al. 1996).

The present study describes the physiological condition of daily cohorts of cypris larvae of the barnacle Balanus amphitrite, and explores the potential relationship between the physiological quality of cyprids and substratum exploration behavior on different surfaces in still and moving water. This preliminary study will provide a framework for investigating the importance of temporal variation in barnacle cyprid quality in relation to optimal habitat selection.

Material and methods. Experimental organisms: Cypris larvae of the barnacle Balanus amphitrite were obtained from a stock of adult individuals maintained at the Duke University Marine Laboratory (DUML) and reared in batch culture on Skeletonema costatum at $28^{\circ} \mathrm{C}$, as described by Rittschof et al. (1984). The cyprid stage was reached $4 \mathrm{~d}$ after hatching. Cyprids were then stored in the dark at $4^{\circ} \mathrm{C}$. Cyprids of $B$. amphitrite are inactive and do not attach or metamorphose at this temperature (Rittschof et al. 1984). In our experiments, we monitored daily the exploration behavior of 0 to $12 \mathrm{~d}$ old cypris larvae in relation to their physiological condition, substratum composition and flow conditions at room temperature $\left(21^{\circ} \mathrm{C}\right)$. Before each trial, cyprids were given a period of time to accustom to the ambient temperature.

Physiological condition of larvae: Experiments were carried out during September and October of 1995 at DUML. The physiological condition of cyprids was assessed using an index based on lipid composition. In many invertebrate larvae, neutral lipids, such as TAG, are the primary endogenous energy reserves used for basal metabolism (e.g. growth, behavior, metamorphosis) (Holland 1978, Gallager \& Mann 1986, Ouellet et al. 1992). The quantity of TAG, however, cannot be solely used to estimate the physiological condition of larvae because of its dependency on larval size (Gallager \& Mann 1986). Alternatively, TAG content can be expressed relative to DNA content to yield a ratio that compensates for the size-dependency of TAG. Thus, we used the ratio of TAG to DNA (TAG/DNA) to evaluate the physiological condition of cyprids.

A total of 15 to 20 cyprids were used per vial (sample) for TAG and DNA analyses. Samples $(\mathrm{N}=3)$ were placed into liquid nitrogen immediately upon collection and stored at $-80^{\circ} \mathrm{C}$ until processed. Each sample was homogenized manually with $500 \mu \mathrm{l}$ of distilled water in a glass tissue homogenizer (20 strokes). Separate samples $(250 \mu \mathrm{l})$ of the initial homogenate were used to analyze TAG and DNA concentrations. Lipids were extracted using methods described by Bligh \& Dyers (1959). The solvent system for lipid separation was chloroform-methanol-water $(2 / 2 / 1,8, \mathrm{v} / \mathrm{v} / \mathrm{v})$. The homogenate was rinsed with $250 \mu \mathrm{l}$ of a $\mathrm{KCl}$ solution $(0.88 \%)$ to facilitate the breakdown of lipid-protein bonds (Ouellet et al. 1992). Homogenates were centrifuged at $2500 \mathrm{rpm}(4000 \times \mathrm{g})$ at $4^{\circ} \mathrm{C}$ for two $10 \mathrm{~min}$ intervals. The lipid fraction was removed after each wash and transferred to a clean tube. The solvent was evaporated under a nitrogen stream and lipids were resuspended in a sodium phosphate buffer $(0.5 \mathrm{M}, \mathrm{pH}$ 7.5) with $0.5 \%$ Brij 35 and $3 \mathrm{mM}$ cholate. The concentration of TAG was determined enzymatically using an automated Technicon RA-1000 analyzer (Cantin et al. 1992). Nucleic acid concentrations were determined by fluorimetry as described by Mayrand et al. (1988). This technique is sensitive to nucleic acid concentrations as low as $0.05 \mu \mathrm{g} \mathrm{ml}^{-1}$ (Robinson \& Ware 1988) and relies on the enhanced fluorescence of nucleic acids after introduction of thiazole orange (TO). The percentages of recovery for DNA were $98.3 \pm 4.7$ $(\mathrm{N}=3)$. We used Tris-Ca buffer, $\mathrm{pH} 7.5(\mathrm{NaCl}: 0.1 \mathrm{M}$, Tris: $0.1 \mathrm{M}, \mathrm{CaCl}_{2} \cdot 2 \mathrm{H}_{2} \mathrm{O}: 0.9 \mathrm{mM}$ ) for solutions of TO $21 \mathrm{mM}$, heparin (16.5 units $\mathrm{ml}^{-1}$ ) and RNAse (4.8 units $\mathrm{ml}^{-1}$ ). Stock solutions of Calf Thymus DNA type I were made up with $1 \mathrm{mg}$ of nucleic acid per $\mathrm{ml}$ of Tris-Ca buffer and kept at $-80^{\circ} \mathrm{C}$. Ice-cold Tris-Ca buffer (NaCl: $0.2 \mathrm{M}$, Tris: $0.2 \mathrm{M}, \mathrm{CaCl}_{2} \cdot 2 \mathrm{H}_{2} \mathrm{O}: 1.8 \mathrm{mM}$ ) was added to sub-samples of homogenate $(250 \mu \mathrm{l})$ and centrifuged at $3000 \times g$ for $10 \mathrm{~min}$. As described by Mayrand et al. (1988), different tubes were prepared for the determination of total nucleic acids for the quantification of DNA (homogenate, heparin, RNAse and $\mathrm{TO}$ ), and to determine the homogenate fluorescence. Tris-Ca was added to obtain a final volume of $1 \mathrm{ml}$ in each tube. Two background tubes were done for each day, with Tris-Ca, heparin and TO. The 'DNA' tubes of each sample were incubated at $37^{\circ} \mathrm{C}$ for 20 min, while the 'total', 'blank' and 'background' 
tubes were kept at $<4^{\circ} \mathrm{C}$. After incubation, TO was added to all the tubes, except to the 'blanks'. DNA amounts were measured with a Perkin Elmer LS50 spectrofluorimeter at $25^{\circ} \mathrm{C}$. Readings were done at EX $511 \mathrm{~nm}$ with a band width of $3 \mathrm{~mm}$ and EM $533 \mathrm{~nm}$ with a band width of $5 \mathrm{~mm}$.

Larval behavior trials: The methodology used to examine exploratory behavior of cyprids has been previously described (Walters et al. 1999). Experimental settlement plates $(8.5 \times 8.5 \times 0.1 \mathrm{~cm})$, on which were drawn reference grids at $0.5 \mathrm{~cm}$ intervals with an indelible marker, were cut from dark-green plastic. Four plate treatments were used: (1) clean, (2) biofilm, (3) $1 \mathrm{wk}$ fouled and (4) $2 \mathrm{wk}$ fouled. Clean surfaces had previously been aged in flowing seawater in the laboratory for $1 \mathrm{wk}$, and were cleaned with paper towels to remove the microbial film immediately before use in our trials. Biofilm surfaces were soaked in the laboratory in running seawater for $1 \mathrm{wk}$ prior to the start of the trials, but had no macro-organisms present on their surfaces. Fouled surfaces were attached face-down to a $1 \mathrm{~cm}$ diameter Vexar ${ }^{\circledR}$ mesh and PVC pipe frame placed ca $20 \mathrm{~cm}$ under a floating dock to be colonized by the natural fouling community for 1 or $2 \mathrm{wk}$. During our experiments, fouling organisms recruiting onto experimental surfaces included barnacles, bryozoans, hydroids, serpulid and spirorbid polychaetes, amphipods and ascidians (see Walters et al. 1999 for species list). Mean cover was ca 15 and $85 \%$ on 1 and 2 wk fouled treatments, respectively. Current speeds under the dock ranged from 0 to $15 \mathrm{~cm} \mathrm{~s}^{-1}$ (Culliney 1969).

In the still water trials, each experimental surface was placed, one at a time, in a plastic chamber $(13.5 \mathrm{~cm}$ length $\times 13.5 \mathrm{~cm}$ width $\times 4.0 \mathrm{~cm}$ height) attached to the bottom with electrical tape (Walters et al. 1999). The chamber was then placed on bricks in an opaque plastic enclosure to minimize light exposure. Observations on clean and biofilm surfaces were carried out using 0 to $12 \mathrm{~d}$ old cyprids (Table 1). Due to a limited number of available larvae, both fouled treatments were run with $0,3,6$ and $10 \mathrm{~d}$ old cyprids (Table 1). Approximately 500 cyprids were used in each trial at room temperature.

In the flow trials, the experimental chamber was similar in dimensions to the one used in still water and had running seawater supplied through a tube fixed at one end of the chamber attached to a $2 \mathrm{~cm}$ diameter plastic T-joint with 20 uniformly spaced $1.5 \mathrm{~mm}$ diameter holes along its length. The opposite end of the chamber was removed and replaced with $0.45 \mu \mathrm{m}$ Nitex ${ }^{\circledR}$ mesh letting water flow through. Flow rates used averaged $5.2 \pm 2.1 \mathrm{~cm} \mathrm{~s}^{-1}$ (mean $\pm \mathrm{SE} ; \mathrm{N}=36$ ). This mean flow rate represented the overall flow rate in the experimental chamber. Flow speeds near the surface were further reduced and highly variable when fouling organisms were present. Flow trials were run with 0,3 and $6 \mathrm{~d}$ old cyprids (Table 1). Approximately 500 cyprids were used in each trial at $21^{\circ} \mathrm{C}$.

An endoscope and videotape recording set-up allowed us to observe cyprids while actively exploring the substratum. This set-up has been previously described in Walters et al. (1999). It consisted of an Olympus K17-18-00 endoscope $(1.7 \mathrm{~mm}$ diameter, $186 \mathrm{~mm}$ length) attached to a Cohu Inc. video camera via a Schölly Fiberoptics GmbH C-mount zoom adapter (model W-7819). The camera was attached to a micromanipulator, allowing 3-dimensional movement inside the chamber. Video output from the camera was sent to a VCR and then to a monitor. An Olympus $250 \mathrm{~W}$ highintensity xenon light source (model ILV-2) provided cold light to the tip of the endoscope via an external fiber optic light guide. A cardboard panel, placed over the external enclosure, eliminated external light sources inside the experimental chamber. The endoscope was set 2 to $4 \mathrm{~cm}$ from the experimental surface and provided a top view of the cyprids while exploring the substrata. Observational bouts in each trial lasted $20 \mathrm{~min}$.

Larval behaviors were recorded in both still water and flow trials. Only individuals actively moving over the surface were considered to be actively exploring. This movement was a result of crawling, swimming, and hopping (Walters et al. 1999). Hopping is defined here as short individual jumps that are suddenly initiated by stationary cyprids. Hopping was the most frequently observed movement in trials. Duration of movement and distance of travel while individuals were actively exploring a surface were only measured in flow trials. In still water, individuals were often

Table 1. Summary of observations $(x)$ carried out during the present study. S: trial runs in still water; $F$ : trial runs in $5.2 \pm$ $2.1 \mathrm{~cm} \mathrm{~s}^{-1}$ flow

\begin{tabular}{|c|c|c|c|c|c|c|c|c|}
\hline \multirow{3}{*}{$\begin{array}{l}\text { Age of } \\
\text { cyprids } \\
\text { (d) }\end{array}$} & \multicolumn{8}{|c|}{ Plate type } \\
\hline & \multicolumn{2}{|c|}{ Clean } & \multicolumn{2}{|c|}{ Biofilmed } & \multicolumn{2}{|c|}{1 wk fouled } & \multicolumn{2}{|c|}{$2 \mathrm{wk}$ fouled } \\
\hline & $\mathrm{S}$ & $\mathrm{F}$ & $\mathrm{S}$ & $\mathrm{F}$ & $\mathrm{S}$ & $\mathrm{F}$ & $\mathrm{S}$ & $\mathrm{F}$ \\
\hline 0 & $x$ & $x$ & $x$ & $x$ & $x$ & $x$ & $x$ & $x$ \\
\hline 1 & $x$ & & $x$ & & & & & \\
\hline 2 & $x$ & & $x$ & & & & & \\
\hline 3 & $x$ & $x$ & $x$ & $\times$ & $x$ & $x$ & $\times$ & $\times$ \\
\hline 4 & $x$ & & $x$ & & & & & \\
\hline 5 & $x$ & & $x$ & & & & & \\
\hline 6 & $\times$ & $x$ & $x$ & $x$ & $x$ & $x$ & $x$ & $x$ \\
\hline 7 & $x$ & & $x$ & & & & & \\
\hline 8 & $x$ & & $x$ & & & & & \\
\hline 9 & $\times$ & & $\times$ & & & & & \\
\hline 10 & $x$ & & $\times$ & & $x$ & & $x$ & \\
\hline 11 & $x$ & & $\times$ & & & & & \\
\hline 12 & $x$ & & $x$ & & & & & \\
\hline
\end{tabular}




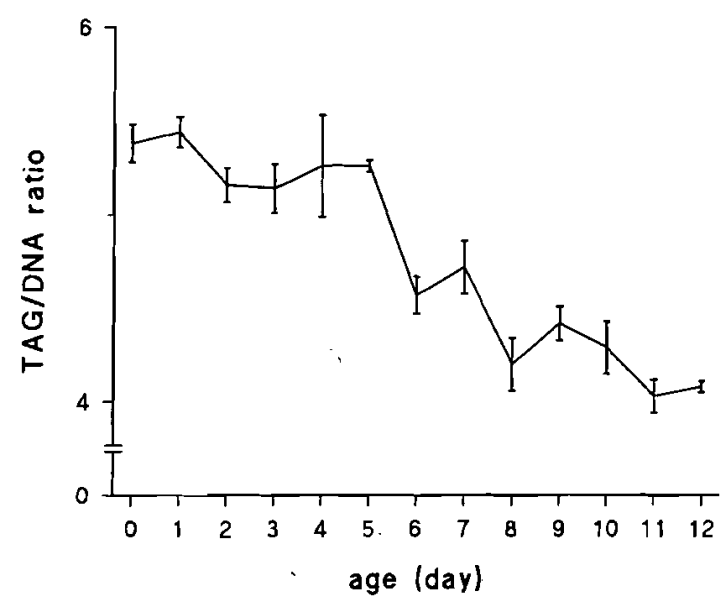

Fig. 1. Balanus amphitrite. Temporal variation in TAG/DNA ratio (mean $\pm \mathrm{SE}, \mathrm{N}=3$ ) of 0 to 12 d old laboratory-reared cyprids

immobile or side-crawling. Side-crawling is defined as individuals crawling on their sides by moving their thoracic appendages (Walters et al. 1999). These behaviors were not considered active exploration behaviors. In addition to the number of individuals actively exploring a surface, the duration that larvae remained immobile or side-crawling on the substratum after initial encounter before returning to the water column was also measured in still water trials $(N=10)$. These data were used as an indirect measure of 'plate attractiveness', assuming that a larvae will leave an unattractive plate rapidly.

Data analyses: A 1-way ANOVA was used to determine if TAG/DNA ratio was influenced by the age of the barnacle cyprids. Tukey's multiple comparison test was used to determine which means were significantly different. Due to the highly variable responses of larvae and unbalanced experimental design, all other comparisons are qualitative.

Results. TAG/DNA ratios: The physiological condition of cyprids decreased significantly over time

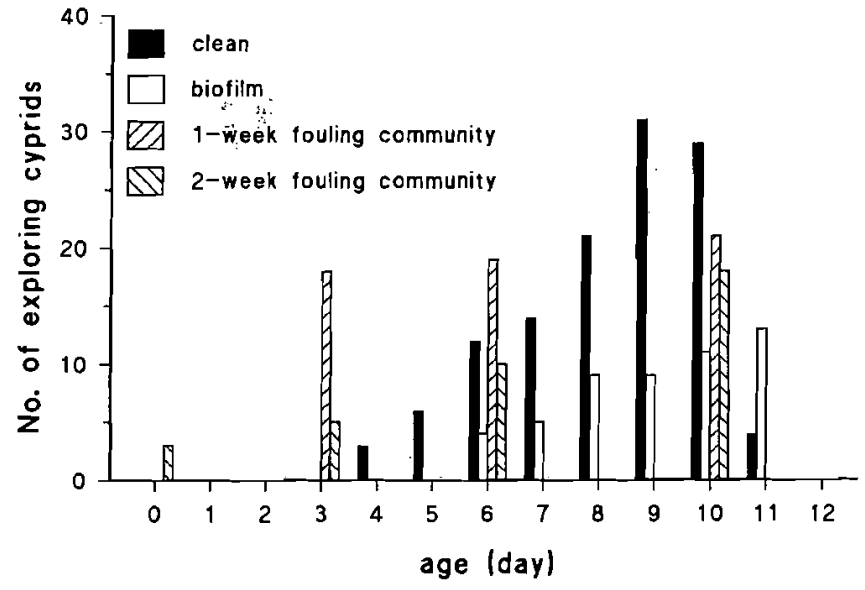

Fig. 2. Balanus amphitrite in still water. Temporal variation in the number of exploring cyprids, 0 to $12 \mathrm{~d}$ old individuals, on 4 surface treatments. Approximately 500 cyprids were used in each trial

(p < 0.001) (Fig. 1, Table 2). At an early age (0 to $5 \mathrm{~d}$ ), the TAG/DNA ratio of cyprids appeared fairly stable (see multiple comparisons in Table 2), varying between maximum and minimum values of 5.44 and 5.14, respectively (Fig. 1). A large decrease then occurred for individuals between 5 and $8 d_{\text {; }}$ the TAG/DNA ratios dropped from 5.26 to 4.20 during this period. The physiological condition of cyprids remained relatively constant in the older cohort of individuals $(8$ to $12 \mathrm{~d}$ : see Fig. 1 and multiple comparisons in Table 2).

Larval behaviors in still water: The number of exploring cyprids (crawling, swimming, hopping) generally increased with age (Fig. 2). This response, however, appeared to vary with plate type. For example, $2 \mathrm{wk}$ fouled plates were explored by individuals as young as $0 \mathrm{~d}$ (Fig. 2). No other plate types were explored by this cohort. Two wk fouled plates continued to be explored by 3, 6 and $10 \mathrm{~d}$ old individuals and the number of exploring cyprids appeared to increase with age. One wk fouled plates started to be explored by $3 \mathrm{~d}$ old cyprids (Fig. 2). The number of exploring

Table 2. Summary of 1 -way ANOVA performed on TAG/DNA ratios $(\mathbf{N}=3)$ in relation to age of cyprids. Multiple comparisons were carried out with a Tukey test. Ages (d) are presented by increasing order of TAG/DNA ratio. Non-significant differences among ratios are underlined

\begin{tabular}{|c|c|c|c|c|c|c|c|c|c|c|}
\hline Source of variation & & SS & & df & & MS & & $F$ & $\cdot$ & $\mathrm{p}$ \\
\hline Age & & 9.98 & & 12 & & 0.83 & & 11.65 & & $<0.001$ \\
\hline Error & & 1.86 & & 26 & & 0.07 & & & & \\
\hline Total & & 11.84 & & 28 & & & & & & \\
\hline Multiple comparisons & & & & & & $\therefore$ & & & & \\
\hline $11 \mathrm{~d} \quad 12 \mathrm{~d} \quad 8 \mathrm{~d}$ & $10 \mathrm{~d}$ & $9 d$ & $6 \mathrm{~d}$ & $7 \mathrm{~d}$ & $3 \mathrm{~d}$ & $2 d$ & $4 \mathrm{~d}$ & $5 \mathrm{~d}$ & $0 d$ & $1 \mathrm{~d}$ \\
\hline
\end{tabular}




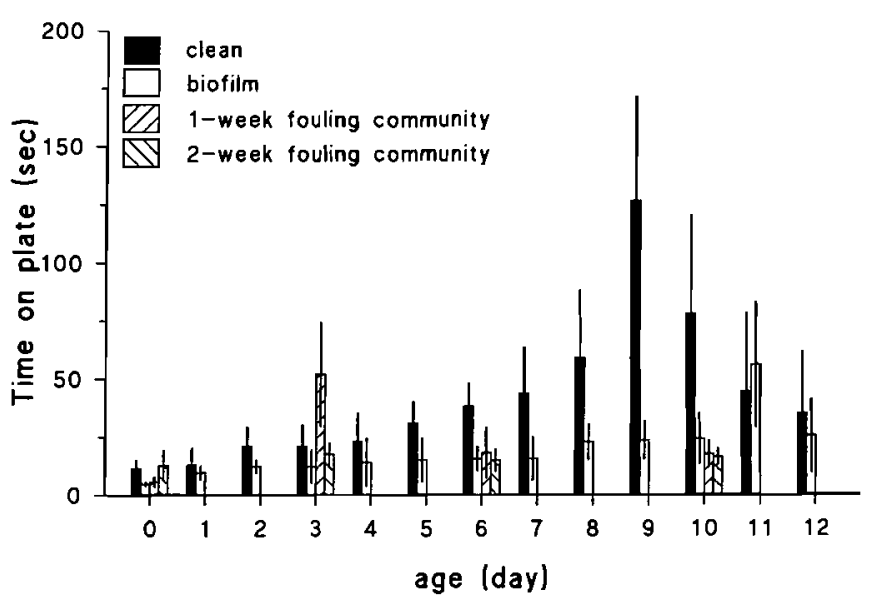

Fig. 3. Balanus amphitrite in still water. Amount of time (mean $\pm \mathrm{SE}, \mathrm{N}=10$ ) spent by 0 to $12 \mathrm{~d}$ old cyprids from initial surface contact to their return in the water column on 4 surface treatments

individuals in 1 wk fouled surfaces stayed fairly constant with increasing age (ca 20 ind. per observational bout of $20 \mathrm{~min}$ ). Clean and biofilm treatments started to be actively explored by 4 and $6 \mathrm{~d}$ old larvae, respectively (Fig. 2). Again, the number of exploring individuals appeared to increase with age. This number, however, dropped dramatically from Day 9 through Day 12 (Fig. 2). In fact, by Day 12, no exploring cyprids were observed.

Duration of time spent by cyprids on plates (nonexploring individuals) in still water is shown in Fig. 3. On clean surfaces, time spent on plates appeared to increase with increasing age up to Day 9 (Fig. 3). However, between Days 9 and 12, time greatly decreased. On the biofilmed surfaces, there was also a small increase from Day 0 to Day 11, after which a decrease was observed (Fig. 3). The shape of both these curves (Fig. 3) mirrored the larval exploration curves (Fig. 2) on these plate types. On both types of fouled surfaces, time spent on surfaces peaked on Day 3.

The overall behavior of cyprids (time budget) did not vary much with age (Walters et al. pers. obs.). For example, side-crawling individuals appeared to be more mobile with age while on their side in still water trials. Individuals also appeared to be more tolerant to encounters with conspecifics with age. Only 1 cyprid settled ( $3 \mathrm{~d}$ old individual) under still water.

Larval behaviors in flow: At the tested flow rate, on Day 0 , there were larvae exploring all plate types (Fig. 4). Exploration was greatest on biofilmed surfaces for Day 0 individuals, and greatest for clean and fouled surfaces for $3 \mathrm{~d}$ old individuals (Fig. 4A). Duration of exploration (Fig. 4B) was also greatest in $3 \mathrm{~d}$ old cyprids (max.: $778 \mathrm{~s}$ ) as well as distance

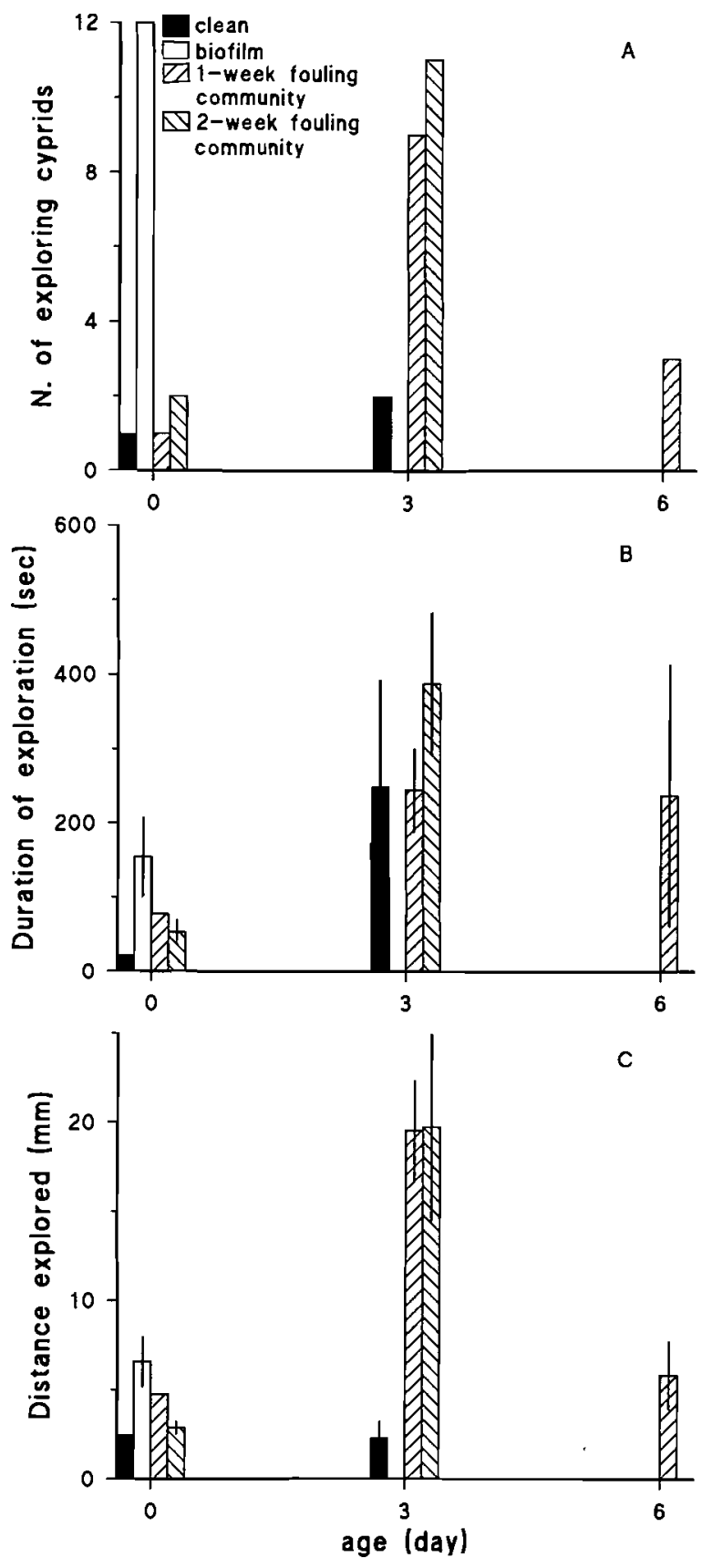

Fig. 4. Balanus amphitrite in flow. (A) Temporal variation in the number of exploring individuals, (B) duration of active exploration (mean $\pm \mathrm{SE}, \mathrm{N}=5$ ), and (C) distance covered while exploring surface (mean $\pm S E, N=5$ ) by 0,3 and $6 \mathrm{~d}$ old cyprids on 4 surface treatments. Approximately 500 cyprids were used in each trial

explored (Fig. 4C) (max.: $39.6 \mathrm{~mm}$ ). Nine larvae were found attached to the substratum surfaces during our observations. Of these, 6 where from the $3 \mathrm{~d}$ old cohort, 1 from the $0 \mathrm{~d}$ old cohort and 2 from the $6 \mathrm{~d}$ old cohort. 
Discussion. In many marine benthic species, the competent larval phase is solely responsible for exploration and subsequent attachment in suitable habitats (e.g. Bourget 1988, Walters 1992, Satuito et al. 1996). In these highly specialized non-feeding larvae the stored energy will decrease over time (e.g. Satuito et al. 1996, Jarrett \& Pechenik 1997). Time, thus, becomes a determinant factor for successful attachment and metamorphosis, and in turn, for distribution and abundance of adult individuals. Many studies have documented decreased energy reserves in barnacle larvae as the larvae age (Holland \& Walker 1975, Lucas et al. 1979, Satuito et al. 1996, Jarrett \& Pechenik 1997). Decreasing energy reserves will reduce larval quality and impede attachment (Rittschof et al. 1984, Satuito et al. 1996). Although the number of studies looking at the importance of endogenous factors in explaining settiement processes are increasing, to date none has examined the impact of depleting reserves on pre-attachment exploration behavior in cyprids.

Our study confirms that the physiological condition of cyprids of Balanus amphitrite decreases with time (Fig. 1). This response curve is similar to those on cyprid storage protein consumption presented on the same species by Satuito et al. (1996) and organic content depletion by Jarrett \& Pechenik (1997) on Semibalanus balanoides. Satuito et al. (1996), however, observed a first significant drop in storage protein with $3 \mathrm{~d}$ old cyprids. In the present study, the first significant decrease was observed with cyprids aged between 5 and $6 \mathrm{~d}$. This difference could be related to the water temperature we used to store cyprids $\left(4^{\circ} \mathrm{C}\right)$. Prolonged cyprid aging at low temperature is known to modify settlement competence (Satuito et al. 1996) as well as to impede larval development (Crisp 1988). Cyprid metabolism (e.g. lipid consumption) could also be reduced at low temperature (Pechenik et al. 1993). The absence of a significant drop at an early age could alternatively be attributed to simple individual variations in the condition index of cyprids. The number of actively exploring cyprids varied with age, with values increasing up to a threshold value, then decreasing. Threshold values were observed in both flow regimes (Figs. $2 \& 4 \mathrm{~A}$ ). Similar relationships have been observed on numbers of attached or metamorphosed barnacles in laboratory assays (Lucas et al. 1979, Rittschof et al. 1984, Pechenik et al. 1993, Satuito et.al. 1996). Settlement in these studies still occurred with cyprids older that $12 \mathrm{~d}$ regardless of temperature. The absence of any substratum exploration displayed by $12 \mathrm{~d}$ old cyprids in the present study remains, in that context, unclear. Furthermore, we were not able to correlate the large drop in the TAG/DNA ratio observed between 5 and 6 d old cyprids to any particular variations in the exploration behavior. Satuito et al. (1996), for instance, observed that settlement peaked with $3 \mathrm{~d}$ old cyprids, an age characterized by a very large drop in storage protein. In this study, exploration started with 4 and $6 \mathrm{~d}$ old cyprids on clean and biofilmed plates, respectively (Fig. 2). Fouled surfaces even displayed exploration with 0 and $3 \mathrm{~d}$ old cyprids. These latter results confirmed that larval exploration varies with surface type (see Walters et al. 1999).

Depletion of energy is known to reduce success in metamorphosis (Lucas et al. 197.9) and post-metamorphic growth (Pechenik et al. 1993). In this study, cyprids older than $9 \mathrm{~d}$ showed a decreasing exploration behavior on clean and biofilm treatments in still water (Fig. 2). In these trials, the time spent on surfaces by non-exploring individuals before returning to the water column (Fig. 3) probably also reflects the fact that surface discrimination decreases as the cyprids age. However, we cannot rule out that cyprids held at $4^{\circ} \mathrm{C}$ for a long period could also need more time to recover. Except in fouled treatments, individuals spent more time on plates as age increased (up to a threshold value) and became more tolerant to overcrowding (increased contacts with other cyprids).

Water flow also affected the response of cyprids (Fig. 4). Both clean and biofilm plates became attractive to cyprids as young as 0 and $3 \mathrm{~d}$ in flow (Fig. 4A). No individuals from the same cohorts were observed exploring these surface types in still water (Fig. 2). Water movement has been shown to increase settlement and attachment in Balanus crenatus (Miron et al. 1996) as well as for $B$. amphitrite (Walters et al. 1999). Miron et al. (1996) suggested that cypris larvae should seek habitats with high flow rate in order to allow metamorphosed individuals to get more food. Water movement may then induce cyprids to explore any type of substratum. Alternatively, water flow may also induce individuals to stick to any surface encountered in order to avoid being passively dislodged. However, this behavior on clean and biofilm plates was only observed with young individuals ( 0 and $3 \mathrm{~d}$ ). No $6 \mathrm{~d}$ old cyprids explored these surfaces under water flowing conditions (Fig. 4A). Fouled treatments appeared more attractive for 3 and $6 \mathrm{~d}$ old cyprids in flow. The attractiveness of these treatments, however, peaked with $3 \mathrm{~d}$ old individuals. Duration of exploration (Fig. 4B) and distance explored on plates (Fig. 4C) in flow also peaked with $3 \mathrm{~d}$ old cyprids. These results, as well as the peak of exploring (Fig. 4A) and attached cyprids observed with the $3 \mathrm{~d}$ old individuals, are probably related to the overall competency of this cohort to exploration and attachment.

Our results support the findings of Rittschof et al. (1984) and Satuito et al. (1996) on larval competency in the barnacle Balanus amphitrite. Cyprid competency appeared age related and peaked for individuals from 
the $3 \mathrm{~d}$ old cohort. Our results also confirmed Walters et al.'s (1999) results on the larval behavior of $B$. amphitrite in relation to the type of substratum and water flow. Overall, the present study showed that habitat selection, an important process in barnacle population dynamics (Miron et al. 1999), results from a complex relationship involving substratum type, hydrodynamics and larval age (i.e. physiological condition and competency).

Acknowledgements. Funding for this research was provided by Université Laval، NSERC and FCAR grants to E.B. Faculté des sciences et de génie de l'Université Laval and GIROQ provided post-doctoral fellowships to G.M. and L.J.W. We thank Dr B. A. MacDonald for use of his endoscope set-up. Drs D. Rittschof and J. Ramus, Director, provided us with laboratory space at the DUML. Drs $K$. Reinsel and $M$. McClary, and Mrs G. Cannon greatly facilitated this work at DUML. Comments from 3 anonymous referees also helped increase the clarity of the text. This work is a contribution to the program of GIROQ (Groupe Interuniversitaire de $\mathrm{Re}$ cherches Océanographiques du Québec).

\section{LITERATURE CITED}

Bertness MD (1989) Intraspecific competition and facilitation in a northern acorn barnacle population. Ecology 70: $257-268$

Bligh EG, Dyers WJ (1959) A rapid method of total lipid extraction and purification. Can $\mathrm{J}$ Biochem Physiol 37: 911-917

Bourget $E$ (1988) Barnacle larval settlement: the perception of cues at different spatial scales. In: Chelazzi G, Vannini M (eds) Behavioural adaptations to intertidal life. Plenum, New York, p 153-172

Caffey HM (1985) Spatial and temporal variation in settlement and recruitment of intertidal barnacles. Ecol Monogr 55:313-332

Cantin B, Brun LD, Gagné C, Ven Murthy MR, Lupien PJ, Lupien $P$ (1992) Alterations in erythrocyte membrane lipid composition and fluidity in primary lipoprotein lipase deficiency. Biochem Biophys Acta 1139:25-31

Connell JH (1961) Effects of competition, predation by Thais lapillus, and other factors on natural populations of the barnacle Balanus balanoides. Ecol Monogr 31:61-104

Connell JH (1975) Some mechanisms producing structure in natural communities: a model and evidence from field experiments. In: Cody ML, Diamond JM (eds) Ecology and evolution of communities. Belknap, Cambridge, p 460-490

Crisp DJ (1976) Settlement responses in marine organisms. In: Newell RC (ed) Adaptations to environments: essays on the physiology of marine animals. Butherworths, London, p 83-124

Crisp DJ (1984) Overview of research on marine invertebrate larvae, 1940-1980. In: Costlow JD, Tipper RC (eds) Marine biodeterioration: an interdisciplinary study. Naval Institute Press, Annapolis, p 103-126

Crisp DJ (1988) Reduced discrimination of laboratory-reared cyprids of the barnacle Balanus amphitrite amphitrite Darwin, Crustacea Cirripedea, with description of a common abnormality. In: Thompson MF, Sarojini R, Nagabushanam $\mathrm{R}$ (eds) Marine biodeterioration, Oxford and IBH Publ Co, New Delhi, p 409-432
Culliney JL (1969) Larval biology and recruitment of the shipworms Terredo navalis and Bankia gouldi in the Newport estuary, N.C. PhD dissertation, Duke University, Durham, NC

Eckman JE (1996) Closing the larval loop: linking larval ecology to the population dynamics of marine benthic invertebrates. J Exp Mar Biol Ecol 200: 207-237

Gaines S, Roughgarden J (1985) Larval settlement rate: a leading determinant of structure in an ecological community of the marine intertidal zone. Proc Natl Acad Sci USA $82: 3707-3711$

Gaines S, Brown S, Roughgarden J (1985) Spatial variation in larval concentration as a cause of spatial variation in settlement for the barnacle, Balanus glandula. Oecologia 67:267-272

Gallager SM, Mann R (1986) Growth and survival of larvae of Mercenaria mercenaria (L.) and Crassostrea virginica (Gmelin) relative to broodstock conditioning and lipid content of eggs. Aquaculture 56:105-121

Gallager SM, Mann R, Sasaki GG (1986) Lipid as an index of growth and viability in three species of bivalve larvae. Aquaculture 56:81-103

Grosberg RK (1982) Intertidal zonation of barnacles: the influence of planktonic zonation of larvae on vertical distribution of adults. Ecology 63:894-899

Hadfield MG (1998) The DP Wilson lecture: research on settlement and metamorphosis of marine invertebrate larvae: past, present and future. Biofouling 12:9-29

Holland DL (1978) Lipid reserves and energy metabolism in the larvae of benthic marine invertebrates. In: Malins DC, Sargent JR (eds) Biochemical and biophysical perspectives in marine biology. Academic Press, London, p 85-123

Holland DL, Walker G (1975) The biochemical composition of the cypris larva of the barnacle Balanus balanoides $\mathrm{L}$. $\mathrm{J}$ Cons Int Explor Mer 36:162-165

Jaeckle WB (1994) Rates of energy consumption and acquisition by lecithotrophic larvae of Bugula neritina (Bryozoa: Cheilostomata). Mar Biol 119: 517-523

Jarrett JN, Pechenik JA (1997) Temporal variation in cyprid quality and juvenile growth capacity for an intertidal barnacle. Ecology 78:1262-1265

Keough MJ, Downes BJ (1982) Recruitment of marine invertebrates: the role of active larval choices and early mortality. Oecologia 54:348-352

Lucas MI, Walker G, Holland DL, Crisp DJ (1979) An energy budget for the free swimming and metamorphosing larvae of Balanus balanoides (Crustacea: Cirripedia). Mar Biol 55:221-229

Mayrand E, Guderley H, Dutil JD (1988) Effect of morphometric maturity and size on enzyme activities and nucleic acid ratios in the snow crab Chionoecetes opilio. J Crustac Biol 18:232-242

Menge BA, Sutherland JP (1976) Species diversity gradients: synthesis of the role of predation, competition, and temporal heterogeneity. Am Nat 110: 351-369

Menge BA, Sutherland JP (1987) Community regulation: variation in disturbance, competition, and predation in relation to environmental stress and recruitment. Am Nat 130:730-757

Minchinton TE, Scheibling RE (1991) The influence of larval supply and settlement on the population structure of barnacles. Ecology 72:1867-1879

Miron G, Boudreau B, Bourget E (1995) Use of larval supply in benthic ecology: testing correlation between larval supply and larval settlement. Mar Ecol Prog Ser 124:301-305

Miron G, Bourget E, Archambault P (1996) Scale of observa- 
tion and distribution of adult conspecifics: their influence in assessing passive and active settlement mechanisms in the barnacle Balanus crenatus Brugière. J Exp Mar Biol Ecol 201:137-158

Miron G, Boudreau B, Bourget E (1999) Intertidal barnacle distribution: a case study using multiple working hypotheses. Mar Ecol Prog Ser 189: 205-219

Mullineaux LS, Butman CA (1991) Initial contact, exploration and attachment of barnacle (Balanus amphitrite) cyprids settling in flow. Mar Biol 110: 93-103

Ouellet P, Taggart CT, Frank KT (1992) Lipid condition and survival in shrimp (Pandalus borealis) larvae. Can J Fish Aquat Sci 49:368-378

Paine RT (1977) Controlled manipulations in the marine intertidal zone and their contributions to ecological theory. In: Goulden CE (ed) The changing scenes in natural sciences, 1776-1976. Special publication 12, The Academy of Natural Sciences of Philadelphia, Fulton, p 245-270

Pawlik JR (1992) Chemical ecology of the settlement of benthic marine invertebrates. Oceanogr Mar Biol Annu Rev 30:273-335

Pechenik JA, Rittschof D, Schmidt AR (1993) Influence of delayed metamorphosis on survival and growth of juvenile barnacles Balanus amphitrite. Mar Biol 115:287-294

Pechenik JA, Hammer K, Weise C (1996) The effect of starvation on acquisition of competence and post-metamorphic performance in the marine prosobranch gastropod Crepidula fornicata (L.). J Exp Mar Biol Ecol 199:137-152

Rittschof D, Branscomb ES, Costlow JD (1984) Settlement and behavior in relation to flow and surface, in larval barnacle, Balanus amphitrite Darwin. J Exp Mar Biol Ecol 82: 131-146

Robinson SMC, Ware DM (1988) Ontogenic development of growth rates in larval Pacific herring, Clupea pallasi, measured with RNA-DNA ratios in the strait of Georgia, British Columbia. Can J Fish Aquat Sci 45:1422-1429

Satuito CG, Shimuzu K, Natoyama K, Yamazaki M, Fusetani $N$ (1996) Age-related settlement success by cyprids of the barnacle Balanus amphitrite, with special reference to consumption of cyprid storage protein. Mar Biol 127: $125-130$

Underwood AJ, Denley EJ (1984) Paradigms, explanations and generalizations in models for the structure of intertidal communities on rocky shores. In: Strong DR, Simberloff $D$, Abele LG, Thistle AB (eds) Ecological communities: conceptual issues and the evidence. Princeton University Press, Princeton, p 151-180

Waldock MJ, Holland DL (1978) Fatty acid composition of the triacylglycerols of the cypris larva of the barnacle Balanus balanoides during metamorphosis. Mar Biol 46:163-166

Walters LJ (1992) Field settlement locations on subtidal marine hard substrata: is active larval exploration involved? Limnol Oceanogr 37:1101-1107

Walters LJ, Miron G, Bourget E (1999) Endoscopic observations of invertebrate larval substratum exploration and settlement. Mar Ecol Prog Ser 182: 95-108

West TL, Costlow JD (1987) Size regulation in the crustacean Balanus eburneus (Cirripedia: Thoracica). Mar Biol 96: 47-58

Woollacott RM, Pechenik JA, Imbalzano KM (1989) Effects of duration of larval swimming period on early colony development in Bugula stolonifera (Bryozoa: Cheilostomata). Mar Biol 102:57-63

Yule AB, Walker G (1987) Adhesion of barnacles. In:-Southward AJ (ed) Barnacle biology. Balkema, Rotterdam, p 389-402

Submitted: September 7, 1999; Accepted: December 16, 1999 Proofs received from author(s): May 9, 2000
Editorial responsibility: Otto Kinne (Editor), Oldendorf/Luhe, Germany 